\title{
Temporalidade, Ética e Contingência na Pós-Colônia Africana: esperando por Deus em Gana
}

\author{
Bruno Reinhardt ${ }^{1}$ \\ Universidade Federal de Santa Catarina, Florianópolis, Santa Catarina, Brasil \\ E-mail:bmnreinhardt@gmail.com
}




\section{Resumo}

O presente artigo investiga o emaranhamento entre as temporalidades pentecostal e pós-colonial em Gana por meio de uma viagem etnográfica a um retiro de oração. Atwea é uma montanha de esperança, onde peregrinos de todo o país "esperam por Deus" praticando jejuns e orações. Argumenta-se que, diferente de mero reflexo ou reação a um contexto de crise, a prática de "esperar por Deus" (twen awrade ou wait on/for God) deve ser entendida como uma modalidade de navegação ética por tempos inerentemente contingentes. Essa prática oscila e tenta orquestrar múltiplos cronótopos, tempos-espaços narrativos e economias de agência centrados na salvação, nos milagres e na oposição demoníaca. Esperar por Deus aparece assim como uma tecnologia do sujeito que permite aos pentecostais de Gana se engajarem com a contingência pós-colonial, tanto como um contexto de emergência e fechamento temporal quanto como um ambiente prenhe de futuros emergentes.

Palavras-chave: Pentecostalismo. Pós-colonialidade. África. Ética. Temporalidade.

\section{Abstract}

This article investigates the entanglements between Pentecostal and post-colonial temporalities in contemporary Ghana through an ethnographic journey to a "prayer mountain". Atwea is a mountain of hope, visited by pilgrims expecting to "wait for the Lord" through fasting and prayers. I argue that waiting for God is an ethical modality of dwelling and navigating a temporality of crisis, rather than a sterile reaction to it. Analogous to most popular Pentecostal converts' lives in Ghana, this practice is not governed by a single temporality. It oscillates across and strives to orchestrate multiple chronotopes, especially the times of salvation, miracles, and demonic opposition. By doing so, waiting for God becomes a technology of endurance and steadfastness infused by the faithful power of anticipation. It allows Ghanaian Pentecostals to engage with post-colonial contingency as a context of emergency and temporal closure as well as an environment pregnant with emergent futures.

Keywords:Pentecostalism. Post-coloniality. Africa. Ethics. Temporality. 


\section{Introdução}

Teste artigo, examino a condição pós-colonial africana a partir de sua 1 dimensão ética e temporal, caracterizada tanto pelo fechamento de futuros passados quanto pela proliferação de futuros emergentes, gestados cada vez mais em redes transnacionais religiosas islâmicas e cristãs (Larkin; Meyer, 2006). Meu interesse particular é o emaranhamento entre as temporalidades cristã pentecostal e pós-colonial em Gana, assim como as limitações impostas pela socialidade contingente do que Achille Mbembe (2001) chama de “a pós-colônia africana" para a teoria social. Minha narrativa se desenrolará como uma viagem etnográfica de Acra à montanha Atwea, um retiro de oração localizado na região Ashanti de Gana, assim como uma reflexão sobre o estilo de vida de meu amigo e companheiro de jornada, o evangelista popular Richard Agyeman. Conhecida no imaginário popular como uma "montanha ungida", Atwea hoje atrai massas de "renascidos em Cristo" vindos de várias regiões de Gana e pertencentes a diversas denominações pentecostais, que sobem ao seu topo para "esperar pelo Senhor" (wait for/on the Lord ou twen awrade) através de jejuns e orações.

Tendo como pano de fundo o argumento de Ghassan Hage (2009) de que o fenômeno da espera é, por um lado, "quase sinônimo ao ser social" (1), e, por outro, uma perspectiva analítica privilegiada, que projeta nova luz sobre questões antropológicas fundamentais concernentes à temporalidade, agência e ética, eu gostaria de perguntar: o que é "esperar por Deus"? E que tipo de rastro etnográfico essa prática devocional provê para se traçar o entrelaçamento entre pentecostalismo e pós-colonialidade enquanto regimes ético-temporais? Meu objetivo é 
discernir desta prática alguns cronótopos (Bakhtin, 1981; Hill, 1995) da espera cristã em Gana, tempos-espaços narrativos que me permitirão defini-la como um instrumento de navegação temporal por tempos inerentemente contingentes.

\section{O Sujeito Pentecostal da Crise: cristianismo e pós- colonialidade em Gana}

Em seu Esperando por Deus, Simone Weil (1996, p. 196) argumenta que "[...] a atitude que ocasiona a salvação não é uma forma qualquer de atividade $[\ldots]$ ", ela é "a espera ou a imobilidade atentiva e fiel que dura indefinidamente e não se abala". Weil (1996, p. 196) compara o sujeito soteriológico do cristianismo à figura do escravo, "[...] que espera, próximo à porta, para abri-la assim que seu mestre chamar". O sabor quietista da fenomenologia da espera de Weil é de fato alheio ao tipo de cristianismo e ao contexto que abordo nesta ocasião. No entanto, eu gostaria de reter a sua consciência aguçada acerca da espera enquanto uma prática generativa, ou seja, irredutível à mera inabilidade ou incapacidade de agir. A espera cristã é uma disposição ética encorporada (embodied), um "modo somático de atenção" (Csordas, 1993), que Weil (1996, p. 76) associa ao grego hupomoné, utilizado no Novo Testamento com sentido de firmeza escatológica, e que julga diferir, por exemplo, do Latim patientia e seu sentido estoico de espera não afetada ou impassível. Hupomoné é cognato ao sentimento prenhe de antecipação definido por Paulo, o apóstolo, como fé: “[...] a certeza daquilo que esperamos e a prova das coisas que não vemos" (Hebreus 11:1).

A espera da fé é uma autoprojeção em um futuro desejado, cuja atualização, apesar de inteiramente dependente da vontade de Outro, provê o horizonte normativo sob o qual o sujeito cristão pensa, sente e age sobre o presente. Sob essa ótica, a espera cristã não é estacionária. Ela é um padrão afetivo complexo de movimento, paradoxalmente atualizado em sua própria não atualização ou adiamento. A espera da fé é também cheia de perigos e provações, logo ela deve ser cultivada enquanto uma competência, assim como a espera de um caçador ou de um pescador hábil (Ingold, 2000, p. 294-311)². Como elaboro a seguir, o 
principal meio de cultivo dessa disposição temporal pelos pentecostais é a oração, uma prática que, por isso, também condensa as tensões que subjazem essa espiritualidade em Gana (Reinhardt, 2017).

É óbvio que, enquanto uma mistura de graça transcendente e habilidade imanente, evento e processo, "agora" e "não ainda", a espera cristã entra na vida cotidiana e se relaciona com uma multiplicidade de outras esperas: expectativas morais e materiais concernentes à boa vida nos futuros próximos e de médio prazo. De fato, a história dinâmica do cristianismo na África subsaariana pode ser lida como a uma série de justaposições - seja como crítica, coabitação autônoma ou completa “concubinagem" (Mbembe, 1988, p. 32, Bayart, 1989) - entre o telos religioso da salvação e teli seculares permeados por contradições, como a "civilização" da era colonial (Comaroff; Comaroff, 1991), a "soberania" da era nacionalista (Hasting, 1979), e o "desenvolvimento" da era neoliberal (Freeman, 2012). Tendo expandido e se diferenciado em constate diálogo com futuros seculares, e não em oposição dialética a eles, como nos centros hegemônicos da modernidade (Koselleck, 2006), o cristianismo africano é a um só tempo vigoroso e volátil. Ser cristão nestes contextos é, em última instância, esperar por Deus ao constantemente debater, definir e defender na esfera pública e na vida pessoal os limites e limiares separando e articulado a fé à economia, à política e à cultura popular. Esse processo certamente não é singular ao caso africano (Asad, 2003; Garriot; O’Neill, 2008), mas ele se dá com intensidade particular em um contexto onde os projetos cristão e moderno de "quebra com o passado" (Scott, 1999, p. 26; Meyer, 1998) chegaram e avançaram de forma sempre adjacente.

Apesar de complexos, os modos de articulação entre as temporalidades pentecostal e pós-colonial em África têm sido abordados pela literatura de maneira unicausal e utilitária. De acordo com Paul Gifford (2004, p. ix), por exemplo, as igrejas pentecostais cresceram em Gana de forma tão proeminente simplesmente "porque elas prometem uma solução para o problema existencial mais candente dos ganenses: a sobrevivência econômica". Johannes Fabian (1998, p. 114) oferece uma leitura igualmente assentada na precariedade material, apesar de mais existencialmente elaborada, quando argumenta que, para 
os pentecostais populares do Congo, "a oração parece 'funcionar' ao transformar desespero em êxtase". Enquanto Gifford (2004), enfatiza como as frustrações com o telos do "desenvolvimento" gestou entre pentecostais uma fé impaciente, inteiramente redutível a orações mágicas declaradas por "homens de Deus" dúbios, Fabian (1998, p. 114) vê a dimensão autorreferencial da oração "em línguas" - essa prática com intenso investimento moral e físico do fiel, mas sem conteúdo semântico - como uma manifestação do que chama de "o Espírito do desespero", uma tentativa compulsiva de domesticar um tempo indomesticável, um Sísifo concentrado em uma tarefa impossível.

Teorias da privação são eventualmente enriquecidas por autores que representam o reavivamento pentecostal africano como reflexo de processos sociais mais complexos, como aqueles que destacam suas afinidades eletivas com o "Espírito do neoliberalismo" (Hilgers, 2012, p. 86), seja pela sua concepção antitradicionalista e globalista de conversão, seu foco na autorrealização moral e material ou sua sacralização ritual do consumo via "teologia da prosperidade" (Comaroff; Comaroff, 2000; Meyer, 2007). Uma opção aparentemente mais favorável tem sido articular o reavivamento pentecostal aos vários processos de redemocratização acontecendo no continente desde os anos 1990. Piot (2010, p. 75), por exemplo, difere frontalmente de Gifford e Fabian ao destacar o aspecto participativo, logo igualitário e empoderador desta espiritualidade ao descrever as igrejas pentecostais do Togo como "horizontais e reticulares", "uma fênix surgindo das cinzas do afro-pessimismo". Diferente de presas fáceis de fazedores de milagres ou ritualistas compulsivos, Piot (2010, p. 76) representa pentecostais como cidadãos autônomos, que

[...] andam com suas cabeças altas, recusando de forma orgulhosa a herança colonial/pós-colonial a eles imposta. Eles vivem vidas com propósito e disciplina, e encontram prazer na louvação. Esse poder de iniciativa vem não de fora ou de cima, mas parece emanar inteiramente deles mesmos.

Minha intenção não é corroborar nem rejeitar nenhum desses diagnósticos generalistas. Suas divergências já exemplificam a ampla variedade empírica assumida por esse movimento religioso na prática. 
Gostaria de me contrapor ao procedimento metodológico que subjaz essas representações, sejam elas mais ou menos positivas: a tendência a dissolver a diferença da espera cristã nas esperas seculares ao reduzir o estatuto da primeira a mero reflexo ou resistência (Cannel, 2006). O teólogo e bispo pentecostal sul-africano Nmbumiso Ngada caminha em direção similar quando argumenta que: “Os eventos da nossa história têm sido registrados como se tudo pudesse ser simplesmente acessado pela sociologia ou antropologia. Nós gostaríamos de escrever a nossa própria história sob o ponto de vista do Espírito Santo" (Kirsch, 2010, p. 89).

Meu objetivo aqui não é simplesmente assumir tal empreitada, que caberia aos próprios pentecostais. Gostaria, no entanto, de tomar o alerta do bispo como uma fonte de reflexividade crítica acerca dos imperativos seculares das ciências sociais, incluindo sua gramática da agência, da ética, e da temporalidade (Asad, 2003; Mahmood, 2009; Marshall, 2009; Hirschkind, 2017). Sendo assim, tomarei a espiritualidade pentecostal não como uma "identidade" religiosa, mas, sobretudo, como um agregado de "tecnologias do sujeito" (Foucault, 1997), artes de viver, práticas generativas ou autopoiéticas (Faubion, 2001) de cuidado de si que atualizam a espera Cristã enquanto uma competência encorporada (embodied), dotada de uma historicidade se não singular, pelo menos potencialmente singular. Esse “equipamento" (Foucault, 2005) éticoespiritual é certamente integrado ao contemporâneo africano, mas não de maneira causal e exógena. As affordances éticas (Keane, 2015, p. 27-31) nele embutidas permitem aos conversos habitar o mundo que os cerca, ou seja, instalar-se existencialmente em seu interior, tonar sua estranheza familiar, e assim produzir suas próprias formas de emaranhamento e navegação temporal. Mas como se define esse contemporâneo?

Aqui gostaria de esclarecer o modo como entendo o tema em torno do qual se organiza este dossiê: a noção de pós-colonial. Sigo assim o antropólogo jamaicano David Scott, que contrasta a consciência histórica que chama de "anticolonial" e qualifica como Romântica e utópica, com a sua versão propriamente "pós-colonial", que ele toma como fundamentalmente Trágica. Essa disposição temporal se aguça com o fim da Guerra Fria e emerge da própria desilusão com a espera 
por soberania e seus aparatos e valores correlatos, como a "economia nacional" e a autodeterminação coletiva e individual. Nesse contexto,

[...] a historicidade teleológica que enfatiza a transição dos males do colonialismo para as virtudes prometidas pelo estado-nação soberano passa a aparecer não exatamente como um erro ou um engodo, mas como algo que se esgotou, que não oferece mais energia crítica suficiente para reconfigurar e renovar os futuros. (Scott, 2014b, p. 806)

Processo similar de exaustão de teleologias, esperas e de esperanças seculares tem sido observado no caso africano. Mbembe define a historicidade pós-colonial africana como um tempo convoluto, em que "[...] o horizonte futuro está aparentemente fechado, enquanto o horizonte do passado aparentemente se esvaiu [...]" (Mbembe, 2001, p. 17) e Piot (2012) associa o ocaso das utopias nacionalistas a um sentimento difuso de perda de orientação temporal, que ele chama de "nostalgia pelo futuro". A relação da maioria dos ganenses com seu líder nacionalista máximo, Kwame Nkrumah, me parece similar. Antes reconhecido por epítetos como Osagyefo (o salvador) e Asomdwehene (príncipe da paz, referência a Isaías 9:6), a figura de Nkrumah hoje após décadas de ditaduras unipartidárias e redemocratizações - evoca para a maioria dos ganenses a beleza melancólica de um futuro abortado.

Não apenas o tempo longo da utopia, mas também o tempo médio, do planejamento racional dos recursos e das expectativas, parecem ter sido engolidos por preocupações crescentes com as urgências materiais imediatas. Essa "orientação para a sobrevivência" (surivalist orientation) (Simone, 2004, p. 9) caracteriza uma grande parcela da população de Gana excluída pelos "saltos" do capitalismo global (Ferguson, 2006, p. 25-48), logo relegada à informalidade econômica e à falta de um salário mensal e a sua capacidade de assegurar futuros de médio prazo para se investir. Essa vida flutuante, centrada na espera ansiosa (Honwana, 2012) ou entediada (Main, 2007) pelo porvir, inclui grande parte dos pentecostais, ameaçando de fato ossificar a espera da fé via saturação.

O tempo da sobrevivência neoliberal é especialmente fértil para o florescimento de geografias erráticas, que tragam o "aqui", incluindo novas formas de acúmulo, em "dimensões místicas subterrâneas" 
(Simone, 2004, p. 7), como a bruxaria e o oculto (Geschiere, 1997). Tal obsessão com o constante mascaramento da realidade através de duplos predatórios tem sido abordada por antropólogos como o imaginário espectral próprio a sociedades marcadas por uma profunda crise de autoridade e legitimidade (Apter, 2005, DeBoeck, 2011), o rumor sendo sua mídia mais propícia de disseminação. Dinâmica similar de fato afeta o pentecostalismo em Gana, onde "homens de deus" aparecem no imaginário popular ora como exemplares morais a serem emulados, ora como tricksters avançando agendas ocultas (Shipley, 2009).

Essa representação sombria do contemporâneo africano deve ser matizada, sob risco de sermos novamente capturados por uma ideia de África "no negativo", com uma longa história no Ocidente (Mudimbe, 1988; 1994). Primeiro, como destacam Comaroff e Comaroff (2012), a qualidade incerta da vida urbana africana tem se mostrado cada vez mais como uma versão premonitória de processos globais de larga escala avançados pelo neoliberalismo, incluindo a academia, o que os leva ironicamente a argumentar que a Euro-América estaria "evoluindo" na direção da África. Segundo, mais do que um mero fechamento do porvir, que incita nostalgia por futuros passados ou ansiedade, a temporalidade pós-colonial africana é antes de tudo pluralista (Reinhardt, 2014). Seu contemporâneo é de certa forma antissincrônico, encapsulando "[...] múltiplas durée, feitas de descontinuidades, reversões, inércias e movimentos que se justapõe, interpenetram, e englobam umas às outras" (Mbembe, 2001, p. 14). Tal pluralismo temporal e sua economia da agência impõem forte resistência à teoria social, baseada em oposições simples entre ordem e crise, normas e anomia, enquanto momentos qualitativamente distintos do processo social (Roitman, 2013).

Como acessar de forma eticamente densa "[...] o trabalho [pentecostal] envolvido em tornar a vida possível [...]" (Mbembe apud Shipley, 2010, p. 659) em um contexto em que a palavra "crise" não se refere mais a um evento pontual, mas a um horizonte temporal que se enraizou no próprio cotidiano (Mbembe; Roitman, 1995)? É importante destacar que o "sujeito africano da crise" vislumbrado por Mbembe e Roitman é, antes de tudo, um "sujeito em emergência", no 
duplo sentido desse termo. Por um lado, ele parece estar imerso em um perene "estado de emergência" (Agamben,2010), marcado pela corrosão das estruturas normativas que asseguram a continuidade da duração (durée), assim como a articulação coerente entre passados, presentes e futuros. Por outro, ele é também um "sujeito emergente", caracterizado pelo empreendedorismo criativo, a "rotinização de um registro de improvisações" (Mbembe; Roitman, 1995, p. 326) e várias estratégias de imaginar e habitar futuros, onde eu incluiria as artes do viver pentecostais.

Antes de me referir a essa dinâmica no caso da "espera por Deus" em Atwea, eu gostaria de dar tons mais concretos à figura do sujeito pentecostal da crise em Gana ao focar minhas atenções no estilo de vida de um evangelista pentecostal popular, que foi também meu companheiro de viagem à montanha de oração. Richard incorpora e exemplifica as formas complexas com que as esperas da fé e da modernidade pós-colonial se emaranham em Gana, incluindo as pressões impostas por essa simbiose temporal tanto em seu projeto religioso quanto na teoria social que tenta abarcá-lo. Esse olhar mais aproximado também nos ajudará a entender como um mesmo movimento religioso pode tornar-se objeto de leituras tão díspares quanto as acima quando evacuado de seus próprios esteios temporais.

\section{Rumo a Atwea: as temporalidades de um evangelista do fim dos tempos}

A primeira vez que ouvi falar em Atwea foi através de meu amigo Richard Agyeman, um pregador de rua que conheci durante meu trabalho de campo em Acra, centrado na pedagogia e nas trajetórias de vida de ministros pentecostais (Reinhardt, 2013). Ciente do meu tema de pesquisa, Richard sugeriu que eu visitasse Atwea, caracterizando-a como um "seminário para os pobres", onde não se precisa nem de dinheiro, nem de contatos para ser admitido. Durante uma das pausas de minha pesquisa principal, decidi seguir seu conselho, aproveitando para convidá-lo a me acompanhar, o que ele prontamente aceitou.

Assim como a maioria dos ganenses relegados à informalidade econômica, Richard vive dia após dia, ou, como ele mesmo diz, “da 
mão para a boca". Mas seu equipamento de sobrevivência, incluindo suas fontes de alimentação e orientação temporal, é mais complexo do que isso. Richard é um "homem de Deus" que, desde que "deu sua vida a Jesus" há vinte anos, vaga pelo deserto da pós-colônia munido com a missão de divulgar o evangelho. Ele considera sua conversão um momento de persuasão divina, atualizado por meio de vasos humanos. Esse evento de "renascimento espiritual" permitiu que ele reclamasse e recebesse uma série de promessas soteriológicas que os pentecostais consideram bíblicas, como ser "preenchido" pelo Espírito Santo e assim começar a cultivar uma relação pessoal e direta com Deus por meio de sonhos, visões, vozes e dádivas espirituais como a glossolalia, a cura, a profecia e a libertação contra demônios.

Outras dádivas espirituais de Richard são tão mundanas quanto qualquer habilidade ou técnica corporal, como a sua memória impressionante, que o permite citar verbatim longas passagens bíblicas e sua oratória persuasiva, tanto em Akan Twi quanto em inglês, apesar de sua escolaridade reduzida. É claro que essas competências foram adquiridas através de tempo, dedicação e emulação. Richard se "alimenta com a palavra" diariamente, medita, ora, testemunha e prega metodicamente e teve uma série de mentores ou "pais espirituais", que serviram como fontes pedagógicas de exemplaridade religiosa. Mas, de acordo com ele, práticas devocionais e relações de aprendizado simplesmente "afinaram" e "amadureceram" aquilo que Deus já havia "plantado" em seu coração desde a sua conversão, como se suas dádivas fossem um conjunto virtual de competências imediatamente concedidas, mas que se atualizaram ou floresceram, lenta e organicamente, ao longo de seu percurso de vida (Reinhardt, 2015). Richard testemunha para a natureza divina do seu chamado evocando sinais cotidianos, como o sentimento de coragem que o acomete antes de interpelar pessoas nas ruas e a intensa satisfação que sente ao falar a elas sobre Cristo, que ele atribui ao Espírito Santo agindo por meio dele. Seu chamado é também corroborado por revelações mais extraordinárias. Richard foi particularmente afetado por um sonho que teve logo após sua conversão. Deus colocou à sua frente uma "tela de TV", onde ele se viu em um ambiente vazio, escuro, inóspito, andando e guiando pessoas 
com uma tocha, a luz da salvação. Em certo momento, eles pararam e Richard distribuiu a cada um de seus seguidores um pedaço de cana de açúcar, que simbolizaria a doçura da palavra de Deus.

O cotidiano de Richard é permeado pelo milagre, que "[...] denota menos uma quebra com o ordinário do que uma intensificação ou transformação dele; o milagre é um ato, uma instância, não de exceção, mas de incepção" (Goldstone, 2014, p. 109). Sob essa ótica, suas dádivas-habilidades naturalmente se entrelaçam com o problema e o tempo da subsistência. Ao tomar as ruas, as praças e o transporte púbico de Acra como a sua paróquia, Richard recebe ofertas monetárias, na maioria das vezes moedas. Ele as utiliza para comprar comida, roupas, e para investir em seu cristianismo, especialmente através de livretos devocionais populares. Richard também é um doador e, periodicamente, reverte seus ganhos módicos em dízimos. Eventualmente, ele agrega doações maiores e utiliza como "dinheiro semente", como pentecostais chamam atos de dispêndio sacrificial na igreja, que indexam a fé em milagres vindouros (Haynes, 2017).

Suas atividades evangelistas também permitiram a Richard tecer redes de reciprocidade com outros ministros e com pessoas que ele "guiou" para o caminho da salvação. Pude acompanhá-lo em viagens pastorais a múltiplas vizinhanças de Acra, incluindo zongos, comunidades de origem Islâmica. Nessas ocasiões, ele interagia com seus conversos de forma mais pausada, conhecendo-os melhor e orientando-os na vida cristã por meio de leituras da Bíblia, aconselhamento e orações. Laços de amizade com conversos e ministros oferecem a Richard uma verdadeira rede de segurança social. Pastores frequentemente o convidam para pregar em suas igrejas e lhes transferem parte de seus dízimos, e seus pupilos "em Cristo" nunca deixariam alguém que eles consideram "um bom homem de Deus" passar sem comida ou sem um local para dormir. Richard de fato não tem uma casa fixa, e mora de acordo como a vontade de Deus ou os favores de seus contatos.

Apesar de suas necessidades básicas serem na maioria das vezes satisfeitas pelos frutos de seu chamado, Richard eventualmente passa por momentos de escassez mais acentuada. Ele os encara com estratégias de emergência, como quando reduz o número de refeições diárias para 
uma, preferivelmente "comida pesada", como fufu, uma massa de origem Ashanti, que "senta" no estômago por mais tempo. Ele também abraça esses eventos críticos através de estratégias emergentes, como ilustrado por um de seus motes: "Quando eu tenho comida, eu como. Quando eu não tenho, eu jejuo e oro"; ou seja, ele "espera por Deus".

Seria fácil representar a estrutura volitiva guiando as decisões de Richard como apenas mais um exemplo de "orientação para a sobrevivência", neste caso obscurecido por uma máscara religiosa. Mas seus regimes cotidianos de improvisações incluem uma preocupação com a coerência, com o que MacIntyre (1984, p. 205) chama de "a unidade [ética] da vida humana", uma "vida que pode ser concebida e avaliada como um todo". Trivializar esse aspecto e reduzir sua pobreza a apenas uma causa exógena orientando suas atividades evangelistas seria assim perder todo e qualquer componente significativo de sua vida.

Richard não é apenas uma pessoa pobre que é cristã. Ele vive sua precariedade como um cristão, convertendo privação infértil em vulnerabilidade fértil, fome em jejum. Seu ascetismo não é mera negação de um mundo caótico, mas uma modalidade metódica de enfrentar e abarcar a sua contingência. A disposição governando a sua conversão de "fome" externamente imposta em "jejum" voluntário não é exatamente o fatalismo de Jó. Ele também jejua quando tem comida e sua firme orientação escatológica não o impede de popular o futuro de médio prazo com esperanças de entrar em um seminário, abrir sua própria igreja, ter sua casa e constituir família. Ele age sobre esses desejos através de orações e jejuns, "dinheiro semente" e planejamento, e não vê essas estratégias como mutuamente contraditórias. Ele tem convicção de que "bênçãos" estão a caminho, mas "no tempo de Deus", e oferece testemunho de muitos milagres já concedidos.

Apesar de sua baixa estatura, humildade e disposição reservada, Richard transpira um forte sentimento de dignidade e de convicção. Ele fala sobre os planos de Deus para a humanidade cheio de gravitas. A autoridade que emana de sua "coragem da verdade" (parrhesia,Foucault,2011) muitas vezes afetava a mim, o descrente, de forma tão densa quanto às suas audiências. Para Richard, a fonte desta autoridade contagiosa é clara, o Espírito Santo, logo ele discordaria tanto de Gifford e Fabian quando estes retratam o pentecostalismo como 
uma espiritualidade da privação, mas também de Piot, quando este assume que o poder de iniciativa dos pentecostais viria "inteiramente deles mesmos".

O Espírito Santo tem que ser cuidado, já que ele cuida de seus vasos, logo o evangelista também se esforçava para não perder o controle de suas decisões e relações, para protegê-las da urgência voraz do mundo da necessidade. Por exemplo, Richard nunca aceitou minhas ofertas de ajuda financeira, mesmo quando eu expliquei que, sendo financiado por dinheiro norte-americano, poderia incluir em meu orçamento "presentes para informantes". Para Richard, esses presentes não eram "dízimos", "ofertas" ou "dinheiro semente". Eles não eram nem mesmo um presente, simplesmente uma ofensiva "doação", já que ele nunca considerou o que me deu - informações, experiências, mas não a salvação - um possível meio de reciprocidade.

Já acostumado a esse modus operandi, quando chegamos à estação central de Acra, no Kwame Nkrumah Circle, para tomar um ônibus para Kumasi, eu fiquei incerto se de fato conseguíramos chegar a Atwea. Mas logo os planos de Richard ficaram claros. Ele não iria viajar de graça. Ele iria "falar a Palavra" e isso nos levaria a nosso destino. Como um "pescador de homens" (Mtt 4:19), Richard esperou pela hora certa de puxar seu anzol verbal, e assim eu também o fiz. Três horas e cinco ônibus depois, ele encontrou um motorista tolerante à sua presença entre os passageiros. Antes de nossa viagem começar, Richard orou pelo motorista e fez "declarações" a ele "em nome de Jesus", para que o Espírito Santo nos garantisse uma viagem segura.

A pregação de Richard naquele dia foi um protótipo de evangelismo pentecostal popular, um gênero retórico preocupado principalmente em incitar nas audiências o desejo de salvação. Mas a sua voz evangelista não foi homogênea. Ela replicou as temporalidades múltiplas que constituem a sua vida, que podem ser arranjadas em torno da noção pré-milenarista de "fim dos tempos" (Harding, 1994). Para pentecostais como Richard, estamos vivendo no fim dos tempos, uma "dispensação", ou período da história da salvação, que precede o "reino milenial" iniciado pela segunda vinda de $\mathrm{Cristo}^{3}$. O fim dos tempos é uma aceleração do tempo na direção do juízo final, cujos sinais básicos seriam um impressionante crescimento tanto da Igreja quanto de forças demoníacas e falsos 
profetas interessados em sabotar o corpo de Cristo. Trata-se de um tempo fora dos eixos, em que "[...] o mundo se encontra deportado, fora de si mesmo, desajustado" (Derrida, 1994, p. 35). Na prática, o fim dos tempos dá vazão a uma variedade de disposições acerca do futuro, incluindo antecipações ansiosas, como ilustrado por uma série de outdoors anônimos espalhados por Acra em 2011, aconselhando à população a se preparar para o Dia do Julgamento, que aconteceria no dia 21 de maio daquele ano. Richard riu de tal alarmismo e argumentou que datações como aquela eram elas mesmas um sinal do fim dos tempos, de acordo com o livro de Apocalipse.

Essa historicidade trágica, apesar de elástica e polêmica; autorreferencial e totalizante, apesar de "entrecortada" (Guyer, 2007) ou orientada para os eventos, foi incorporada pela voz evangelista de Richard durante nossa viagem, que oscilou de forma fragmentária entre uma variedade de "posições de fala" (stances, Hill, 1995) e temporalidades correspondentes. Richard pregou em Twi e começou com uma voz extramundana, exortando sua audiência a "deixar tudo para trás" e prometendo que "quem acreditar no Senhor não perecerá e terá vida eterna e abundante", evocando um sentimento confortante de esperança na vida eterna. Essa voz falava sob o ponto de vista do fim, utilizando-o como um ponto de vantagem para se criticar os valores do senso comum, incluindo esperanças de imigração e idealizações do Norte:

Irmãos e irmãs, pais e mães, a morte pode ser encontrada em Gana ou na América. Para onde quer que vocês vão neste mundo, um dia vocês vão morrer. Você não pode dizer que se você imigrar para outro país você vai deixar de morrer, e nenhum lugar nesse planeta é comparável com os Céus. Eles usam asfalto para construir as ruas na América. A noite, eles ligam a iluminação pública e as ruas são claras e seguras. Eles andam com tranquilidade e segurança com suas famílias. Mas nos Céus, se vocês lerem Apocalipse 21, Ele nos diz que as ruas não vão ser calçadas com asfalto, mas com ouro. Mesmo nosso ouro de Obuari [cidade mineira] é impuro se comparado ao ouro dos Céus. Deus está falando de ouro puro. Nós vamos para a vida eternal não para manusear ouro, mas para andar sobre ele. 
A solução oferecida por esta voz de Richard para as frustrações de sua audiência não foi mover de uma espera prolongada para realizações, mas uma oportunidade de acessar a visão total da vida e esperar de forma diferente: como um sujeito "nascido de novo".

Alguns minutos depois, no entanto, Richard mudou de registro para uma voz miraculosa, centrada nas intervenções divinas neste mundo. Ele compartilhou, excitado, testemunhos sobre pernas defeituosas sendo curadas durante uma cruzada evangelista em Kumasi, um corpo erguendo-se da morte durante uma seção de oração em um necrotério em Acra, e uma alcóolatra "restaurado" por Jesus e "promovido" a um famoso ministro internacional. Esses milagres evidenciaram que o Deus que nos presenteia com a salvação é também um "Deus vivo" e essa voz intramundana incitou na audiência esperanças sobre bênçãos de curto e médio prazo: "você vai conseguir", espere curas, prosperidade, viradas morais, porque "em Jesus, tudo é possível".

Essas cenas de regozijo foram então abruptamente interrompidas por mundos ocultos e sinais apocalípticos. A voz submundana de Richard foi igualmente centrada na fala evidencial dos testemunhos. O testemunho de um ex-Sakawa boy convertido foi utilizado para destrinchar os bizarros rituais utilizados por essa mistura de fraude via internet e praticas "ocultas", que tem habitado o imaginário popular em Gana (OduroFrimpong, 2014). Comentários sobre profetas pentecostais corruptos, enganando suas congregações, mantendo relações sexuais impróprias, e procurando por poderes espirituais com "feiticeiros" exemplificaram como, no fim dos tempos, a confiança se desintegrou mesmo dentro do corpo de Cristo. Os sofrimentos causados pela recente guerra civil na Costa do Marfim, tensões políticas na Tunísia e no Egito e enchentes mortais na Indonésia foram referidas a citações bíblicas, logo sendo abarcadas como o curso natural e divinamente previsto de um tempo fora dos eixos.

A audiência engajou com a performance de Richard de forma variada. Alguns permaneceram indiferentes, outros prestaram intensa atenção e se deixaram levar por sentimentos de fascinação, reverência, arrependimento, esperança, descrença, suspeição, medo, e mesmo entretenimento. Depois de nos transportar por uma verdadeira 
montanha-russa retórica por mais de uma hora, Richard concluiu com uma seção de louvação, entoando canções espirituais e sendo acompanhado em uníssono pela maioria dos passageiros. Enquanto o ônibus se transfigurava em uma igreja móvel, retornamos para onde havíamos começado: a dádiva da vida eterna. Canções populares como Ohene Oreba (O Rei está chegando), anunciavam que Cristo, "nosso guerreiro/protetor" ('Dsabarima ei), "chegará e nos levará para celebrar com ele". E enquanto o motorista lutava para driblar os buracos da estrada, uma canção Nigeriana em inglês nos tragava para outros tempos, repetindo: "Eu tenho um outro mundo em vista. Meu Salvador se foi para me preparar um lugar. Eu tenho um outro mundo em vista..."

Pode-se dizer que, assim como o estilo de vida de Richard, sua voz evangelista oscilante exemplificaria a "proliferação de critérios para a ação eficaz" (Mbembe; Roitman, 1995, p. 342) que caracteriza o sujeito africano da crise. De fato, longe de domesticar a temporalidade da crise, noções como o fim dos tempos asseveram que a norma é e continuará sendo a contingência (pelo menos até o retorno de Cristo). Mas ao fazer isso, essa historicidade pré-milenarista também provê aos conversos instrumentos para habitar esses tempos emergenciais. O que Richard oferece para suas audiências é, por fim, o mesmo equipamento éticoespiritual que o permite lutar por coerência em sua vida cotidiana; não contra a corrente pós-colonial, mas dentro dela.

Trata-se de um equipamento de navegação temporal em que a coerência é buscada através de procedimentos similares ao romance heteroglóssico de Bakhtin (1981), ou seja, não através do estabelecimento de um tempo alternativo homogêneo e bem delineado, mas através de uma orquestração dinâmica de cronótopos, tempos-espaços narrativos dotados de economias específicas de agência: tempos da salvação, dos milagres e das distopias ocultas. Veremos dinâmica similar sendo atualizada por meio das técnicas de oração mobilizadas em Atwea, o atletismo espiritual daqueles que esperam por Deus. 


\section{A Montanha de Oração: pessoas, tempos e agências de Atwea}

Após Richard e eu chegarmos à estação central de Kumasi, não demorou muito até pegarmos uma van para o distrito de Sekyere Central. Desembarcamos por voltas das sete da noite em um pequeno vilarejo localizado no sopé do vale formado pelas montanhas Atwea, Adenkyirewi e Krobo, de onde partiríamos a pé rumo ao topo da montanha de oração. O influxo de peregrinos transformou visivelmente a vida econômica do pequeno assentamento. Lojas familiares oferecem aos fiéis mantimentos básicos e vendedores ambulantes de comida sobem ao topo da montanha duas vezes por dia, atendendo àqueles que optaram por quebrar seu jejum.

A trilha que leva ao topo da montanha é bela, mas longa, íngreme e escorregadia, levando entre 40 minutos e um hora para ser vencida. Jovens locais se oferecem para carregar as bagagens dos peregrinos por algumas moedas. Seus serviços são geralmente demandados, já que visitantes trazem colchões e sacolas com roupas. Congregações inteiras podem ser vistas montanha acima com seus pastores, acompanhados por cadeiras de plástico, caixas de som, púlpitos e Bíblias. O número de "campos de oração" no topo de Atwea se multiplicou ao longo das décadas e uma infraestrutura durável foi lá construída, incluindo geradores, barracões de madeira e casas feitas de rochas extraídas da montanha e cimentadas.

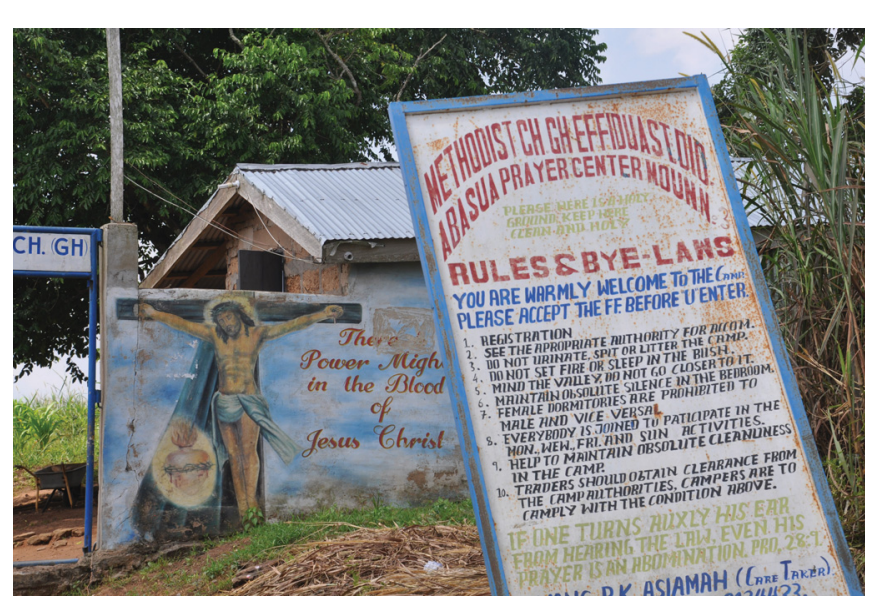

Fonte: Banco de imagens do autor

Richard e eu ficamos no Cento de Orações Abaswa, gerido pela Igreja Metodista, mas aberto ao público em geral. Esse foi o primeiro campo de oração estabelecido na montanha e conta hoje com múltiplas casas de pedra, uma 

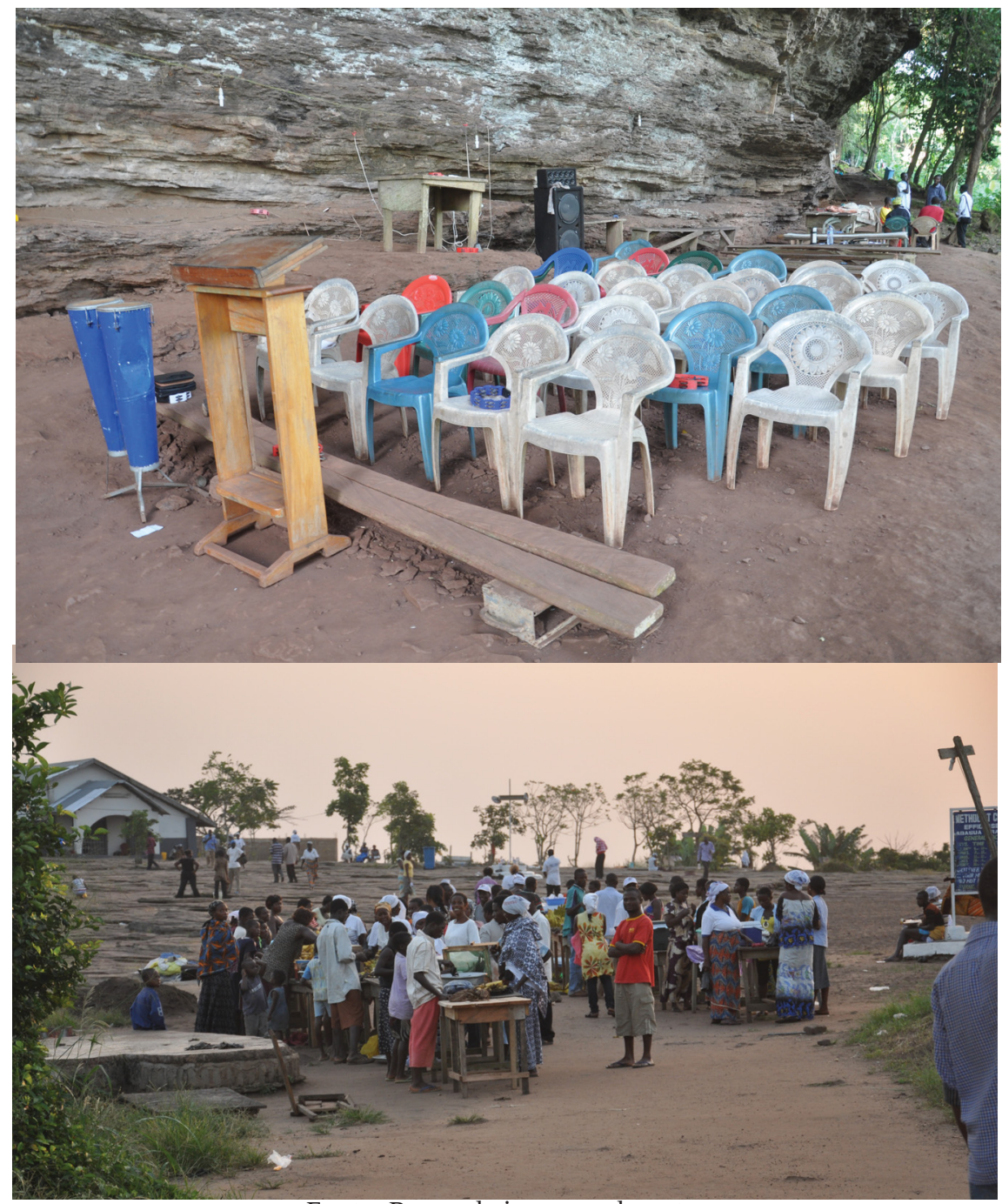

Fonte: Banco de imagens do autor

capela, e uma grande cruz. Os dormitórios são gratuitos. Na entrada, um letreiro recebe os visitantes com hospitalidade, alertando-os para algumas regras básicas de convivência, como a necessidade de se dirigir às autoridades locais na chegada, manter as estruturas limpas e estar ciente de que os dormitórios são separados por gênero.

Enquanto socializávamos em nosso dormitório, Richard e eu conhecemos algumas pessoas e espontaneamente formamos um "grupo de oração". Uma delas foi Akosua ou Sweet Mother, uma profetiza 
Pentecostal com aproximadamente 35 anos de idade, recentemente retornada da Itália, para onde seus pais haviam imigrado 10 ano atrás. Um processo malsucedido de adaptação, somado a persistentes sonhos e "visões noturnas" trouxeram Akosua de volta a Kumasi em 2008, para "fazer o trabalho do Senhor". Lá ela fundou a sua Jesus is the Answer Family Church, após operar como evangelista de rua por dois anos. Naquela ocasião, Akosua estava acompanhada por três de seus "guerreiros da oração": Abekan, Adjei e Sylvester. Alguns motivos os trazendo para Atwea foram: orar pelo crescimento da igreja, por mais "unção", ou graça ministerial, e para interceder por dois membros de sua igreja que estavam doentes.

Akosua é solteira e não tem filhos biológicos. Seu apelido, Sweet Mother, reflete a centralidade do parentesco espiritual nas trajetórias pentecostais em Gana de maneira geral (Reinhardt, 2013; 2016). No caso particular de Sylvester, à época com 18 anos, o parentesco espiritual assume uma versão mais visceral, já que ele perdeu ambos os pais em um trágico acidente de carro em 2009. Sylvester acredita que foi "a mão de Deus" que o levou de encontro à profetiza em uma estrada empoeirada em Kumasi, quando ela o "guiou para Cristo" e, pouco tempo depois, o convidou a mudar-se para sua casa e trabalhar como aprendiz em sua igreja. Sylvester afirmou que Deus sabia que tanto ele quanto a profetiza haviam sido desconectados das pessoas que eles mais amavam, logo essa vulnerabilidade comum seria uma ponte para a regeneração mutua de ambos. Sylvester hoje sonha em se tornar um pastor, talvez abrir um ramo da igreja da profetiza, talvez ter sua própria igreja em Gana ou mesmo na Europa ou América. Ele estava orando para que Deus desvelasse seu futuro.

Outro membro do nosso grupo era Reverendo Ocran, o pastor experiente da igreja Stone Temple International, fundada em Madina, Acra, em 2000. Sua igreja é hoje composta por sete ramos, espalhados por diversas regiões de Acra. Ocran treinou uma série de pastores informalmente durante sua trajetória e recentemente abriu uma Escola Bíblia em sua igreja. Membro original da International Central Gospel Church (ICGC), hoje uma das maiores igrejas pentecostais de Gana, Ocran "renasceu em Cristo" em 1985. Em 1989, um momento de profunda recessão econômica em Gana, ele decidiu tentar a vida na 
Nigéria e "seguir Benson Idahosa", o pioneiro do neopentecostalismo no Oeste africano. Apesar de suas muitas provações, Ocran considera sua experiência na Nigéria um período de renovação espiritual, em que "os Céus se abriram, e Deus começou a falar comigo através de sonhos, quando eu dormia". Seu zelo aumentou e ele começou a "perseguir o chamado" ao fazer evangelismo e conectar-se com "pais espirituais". Ele conseguiu economizar algum dinheiro e voltou para Acra em 1996. Desde então, Ocran casou-se, completou um curso de Teologia na universidade privada gerida pela ICGC e fundou sua própria igreja. Sua situação econômica hoje não é exatamente confortável, mas é bem melhor que a anterior. Ele atribui essas melhorias a Deus, já que "propagar o evangelho lhe leva longe" e continua a fazer planos. Os mais urgentes são: abrir uma biblioteca em sua Escola Bíblica, completar a construção de suas igrejas, que operam em prédios ainda inacabados, e comprar uma van, para transportar sua congregação para retiros de oração. Ele estava orando por essas bênçãos em Atwe, assim como por mais "unção", já que estava prestes a organizar uma cruzada em Acra. "Atwea é um montanha muito poderosa", ele me disse. "Estou esperando grandes milagres aqui".

Justificativas sobre a atração exercida por Atwea se dividiram em dois eixos em nosso grupo. Um deles pode ser chamado de ambiental. O isolamento natural da montanha é considerado condutivo para práticas de fé e exercícios espirituais. Richard, por exemplo, contrastou a tranquilidade de Atwea como o ritmo frenético de Acra, onde o barulho e as distrações da vida cotidiana podem tornar seus ouvidos "surdos para a voz de Deus". Mas isolamento também significa liberdade para se fazer barulho cristão, ou seja, cantar e orar em línguas de forma intensa até a madrugada. A peregrinação para Atwea foi constantemente legitimada através de um recurso figurativo a montanhas bíblicas: Moisés subindo ao Monte Sinai para "aparecer diante do Senhor" (Ex 19), Elias orando por chuva no Monte Carmelo (1 Reis 18), Jesus no Monte da Transfiguração (Mtt 17). Sylvester também descreveu Atwea como um ambiente socialmente condutivo, que o permitia criar laços de amizade com cristãos vindos de todo o país, incluindo "grandes homens de Deus", de quem ele recebia aprendizado e orações. 
O segundo conjunto de justificativas é inteiramente testemunhal: milagres aconteceram em Atwea antes, estórias espalharam e se multiplicaram, e fiéis começaram a vir em massa para orar por vistos, empregos, casamentos, prosperidade, fertilidade 4 . O Espírito de Deus simplesmente "move-se" assim para os pentecostais: em diferentes intensidades, e de acordo com ambientes e pessoas específicas. Atewa parece ocupar um lugar especial em seus planos, apesar dos fiéis eventualmente discordarem sobre como a relação entre essa montanha e Deus deva ser normativamente visualizada, fato comum em lugares de peregrinação (Coleman,2002). Conheci muitas pessoas durante meu trabalho de campo em Acra que receberam seu batismo no Espírito Santo, com a evidência de "falar em línguas" em Atwea, o que também foi o caso com os três acompanhantes de Sweet Mother. Pastores e aprendizes sempre vêm a Atwea para orar pela "unção", a força carismática que permite a ministros operar milagres, pregar persuasivamente e atrair fiéis. Uma série de ministros hoje famosos em Gana são conhecidos por terem recebido a sua unção em Atwea após passarem longos períodos de jejum e oração no topo da montanha: Salifu Amoako, Agyin-Asare, Duncan-Williams, Mensah-Otabil, entre outros. Factuais ou rumorosos, esses testemunhos revelam o que eu considero ser a substância mesma da fama de Atwea: desejo e mimetismo (Tarde, 1969, p. 195-208; Girard, 1976, p. 1-52).

A circulação mimética dos milagres acontecidos em Atwea por meio dos testemunhos é coetânea à circulação mimética do desejo por Deus. O resultado é aparentemente paradoxal: a circulação e intensificação do desejo ele mesmo, uma iteração em pequena ou média escala do "reavivamento" carismático acontecendo em Gana de maneira geral. Ministros populares como Richard, Sweet Mother e seus aprendizes e Ocran desejam ser como esses influentes homens de Deus. Sua imaginação empreendedora insiste em transbordar os limites de sua posição social atual. Afinal de contas, foi o mesmo Deus que eles servem que ergueu esses ministros do anonimato à notoriedade. Eles desejam ter o que esses modelos exemplares têm - igrejas grandes, visibilidade, talvez fama - ao desejarem o que eles desejaram, o Objeto que em última instância transformou suas expectativas em realidade: a 
graça empoderadora de Deus. A busca por esse Objeto comum por meio de procedimentos comuns, como lançar-se em uma vida evangelista nômade, embasam a série de similitudes entre as trajetórias de Richard, Akosua e Ocran, cujos caminhos podem ser pensados como iterações de um mesmo padrão mimético ungido. Mais ainda, eles desejam desejar como seus modelos desejaram em Atwea: submeter a Deus por meio de jejuns e orações, afinar seus instrumentos corporais para receber de Deus e habitar essa promessa com fé. O resultado é uma poderosa máquina de compressão espaçotemporal: Moisés, Eliseu, Jesus, Amoako, Agyin-Asare, Duncan-William, Richard, Ocran, Akosua no Monte Sinai, Monte Carmel, Monte da Transfiguração, Atwea, todos e tudo a um só tempo, esperando por Deus.

Há duas formas de se entender essa expressão, "esperar por Deus", em Atwea. A primeira é ampla. Esperar por Deus é simplesmente passar tempo imerso nesse ambiente de fé, semanas ou meses. Nesse caso, ela indica a totalidade de práticas e experiência acontecendo neste "chão de oração": múltiplos gêneros de oração, cultos organizados por várias igrejas, grupos de leitura da Bíblia e o convívio Cristão cotidiano referido acima por Sylvester. O segundo sentido é mais circunscrito, estando contido no primeiro. Esperar por Deus é "trabalhar na oração", longas sessões de oração em línguas, precedidas por jejuns, durante as quais sofrimentos e desejos são "colocados aos pés de Deus". Elaboro mais sobre esta prática a seguir.

\section{Os Cronótopos da Espera em Atwea}

A figura bíblica mais comum evocada de modo a legitimar a definição estrita de "esperar por Deus" entre os pentecostais de Gana é Genesis 32: 22-31, em que Jacó luta com Deus na forma de um anjo através da noite. A cena exemplifica as recompensas de uma fé resiliente e inclui momentos de grande violência sagrada, como quando o anjo "viu que não poderia dominá-lo", a assim "tocou na articulação da coxa de Jacó, de forma que lhe deslocou a coxa, enquanto lutavam". Jacó não se abala e o anjo é eventualmente exaurido por sua persistência: “'Deixe-me ir, pois o dia já desponta'. Mas Jacó lhe respondeu: 'Não te deixarei ir, a não ser que me abençoes'. O homem lhe perguntou: 
'Qual é o seu nome?' ‘Jacó', respondeu ele. Então disse o homem: 'Seu nome não será mais Jacó, mas sim Israel, porque você lutou com Deus e com homens e venceu'".

A passagem ilustra a centralidade da intensidade física e moral que caracteriza "trabalhar na oração", que pode ser definida como uma forma atlética de se habitar o hiato ontológico entre a volição humana e a soberania divina, o poder da submissão. Tanto a figura bíblica quanto a prática que a atualiza e a sincroniza em Atwea exemplificam a complexa zona cinzenta de agência que existe entre a espera autojustificada que caracteriza a oração e a efetividade técnica inerente ao que Marcel Mauss (1979) chama de "encantamento", mapeando ambos a duas estruturas volitivas: "Que seja feita a sua vontade" (oração) e "Que seja feita a minha vontade" (encantamento). Sem espera não há oração e, como destaca Mauss, ambas as práticas devem ser abordadas não como tipos, mas como polos de um contínuo; e eu destaco: um contínuo em que a espera cristã adquire a sua singularidade ética, logo na qual também pode vir a perdê-la.

Quando nos movemos para dentro da mata escura na noite do dia seguinte, munidos de velas e lanternas, para "esperar pelo Senhor" e reencarnar a luta de Jacó das 9 da noite às 3 da manhã, essa economia ambígua de agência veio à tona em todas as suas potencialidades. Ocran, devido à sua senioridade tanto biológica quanto "em Cristo", espontaneamente tornou-se nosso líder. Líderes de oração são como maestros ou treinadores. Eles orientam a performance de forma participativa e sustentam seus diversos ritmos coletivos, focos de atenção e cronótopos dominantes. Começamos com uma sessão de louvação, canções espirituais cantadas em uníssono por cerca de 20 minutos, com a ajuda de palmas e pandeiros. Louvações são meios musicais de transporte para outros tempos. Elas gestam bolhas semânticas, melódicas e rítmicas que irrompem o cotidiano e afinam os fieis sensorialmente para entrar em relação com Deus. Essas canções engendram simultaneamente "relações de afinamento mútuo" (Schutz, 1951, p. 79) entre os humanos e uma intensificação da presença divina para além de um limiar particular. Dá-se assim um "acordar" coletivo do Espírito Santo, cuja agência - apesar de onipresente - ganha em 
nitidez afetiva durante o fluxo da coperformance musical (Reinhardt, 2015, p. 417-21).

Depois que o ambiente musical lentamente recuou, passamos para uma etapa ritual que chamaria de confissão e arrependimento. Ocran intercedeu: "Contem a Deus como vocês são pequenos e fracos. Como vocês precisam dele. Confessem seus deslizes. Se arrependam. Contem a ele que sem a sua graça, vocês não conseguiriam nem acordar de manhã. Contem a ele porque vocês vieram a essa montanha, porque vocês deixaram as suas famílias para trás, para esperar pelo Senhor". Sua interpelação foi atendida por uma cacofonia de vozes, corpos que andavam de forma caótica, gesticulado, confessando, pedindo perdão e lembrado a Deus de sua grandeza e bondade. O cronótopo da salvação orientava esse procedimento, que não foi nada além de uma reiteração do ato mesmo de conversão: confessar, arrepender-se e submeter seu destino a Cristo. Pode-se dizer que cada atualização ritual da espera por Deus é uma renovação deste pacto primário, que gesta o sujeito renascido em Cristo.

Estávamos prontos para adentrar no cronótopo dos milagres e bênçãos. A dinâmica geral regendo as orações daqui em diante foi uma constante intercalação entre "pontos de oração" e glossolalia, como "Pai, nos dê o poder e a habilidade para fazer seu trabalho" [glossolalia] - "Pai, nos dê a unção para fazer seu trabalho" [glossolalia] - "Pai, nos dê sabedoria para fazer seu trabalho" [glossolalia]. Ocran agia como um verdadeiro treinador. Ele falava por sobre o fluxo de glossolalia, ora animando-o e intensificando-o como comentários como "Mais fogo, mais fogo" ora acalmando-o antes de mudar de ponto de oração com um longo "Amém". Temas como problemas financeiros, de saúde, e familiares foram também adicionados. Akosua citou os nomes e as aflições acometendo os dois membros de sua igreja pelos quais estávamos intercedendo naquela noite.

Os ânimos e estados afetivos que acompanharam esse cronótopo oscilavam ambiguamente entre pleitos submissos e autoaflitivos e antecipações esperançosas de milagres. Ocran nos guiava constantemente a cenas prospectivas, projeções retóricas de bênçãos já recebidas, seguidas por agradecimento, como “Eu vejo a unção chegando! Seu óleo está 
caindo sobre nossas cabeças, oh Senhor! Obrigado Jesus!" Mobilizando técnica similar, Richard uma vez interrompeu a performance e chamou nossa atenção para Samuel 30: 8. “Este é Davi. A sua casa foi atacada e pessoas aprisionadas. Um homem de Deus ungido... Vocês podem acreditar que alguém faria uma coisa tão tola?" Ele então citou o momento em que Davi fala com Deus: "'Devo perseguir este bando de invasores? Irei alcançá-los?' E o Senhor respondeu: 'Persiga-os; é certo que você os alcançará e conseguirá libertar os prisioneiros"”. Richard então nos exortou: "Orem para libertar os prisioneiros", e quando a glossolalia começou, ele continuava gritando "Resgatem todos! Resgatem todos! Deus está do nosso lado. Resgatem todos!" Quando a intensidade da oração em línguas recendeu, cerca de vinte minutos depois, ele declarou: "Está feito! Obrigado Jesus! Obrigado Senhor!"

A qualidade agonística do ponto de oração proposto por Richard acima (resgatar de quem?) foi apenas o começo de uma virada geral para o cronótopo da batalha espiritual. Entramos assim em um ambiente militarizado e sombrio, permeado por ataques verbais ao demônio. Akosua redirecionou nossa atenção para os membros doentes de sua igreja e declarou que "Qualquer pacto demoníaco contra suas vidas está agora desfeito em nome de Jesus". Enquanto a glossolalia reemergia, ela continuava "queimando pactos ocultos" com o fogo do Espírito Santo e eventualmente profetizou: "Neste mundo, nós não vivemos sós, mas com a escuridão e os demônios [...] O Senhor está me dizendo que alguém comprou um terreno, mas ele foi tirado dessa pessoa ilegalmente. Alguém abriu uma loja, mas logo teve que fechála. Sua igreja está vazia, ninguém quer vir. Seu casamento está caindo aos pedaços. Vamos desfazer todos esses ataques aos nossos destinos".

A própria dimensão somática da oração em línguas adquiriu um tom mais agonístico, com sons guturais emitidos por corpos que se balançavam e gesticulavam em fúria. Esse estágio violento da performance alcançou um pico de intensidade quando Ocran tomou a frente novamente e declarou que iria recitar de um manual de oração nigeriano, que havia comprado em Kumasi. A partir desse momento, os participantes engajaram com uma espécie de credo militar em inglês: Ocran lia do livreto na primeira pessoa e os outros participantes 
reproduziam essas palavras seguindo seu exemplo. Abaixo, eu descrevo a fala de Ocran e marco a pausa para a recitação do grupo com um [R]:

Senhor Jesus [R], use a minha boca [R] como uma arma $[R]$ para cancelar meus inimigos [R].

Senhor Jesus $[R]$, use a minha boca $[R]$, como uma metralhadora $[R]$ para afugentar meus adversários [R]

Senhor Jesus [R], use a minha boca [R] como um tanque de guerra $[R]$ para derrubar as montanhas demoníacas dos meus inimigos [R]

Senhor Jesus [R], use minha boca [R] como uma bomba $[R]$ para bombardear o campo dos meus inimigos [R]

Senhor Jesus [R] use minha boca [R] como um submarino $[R]$ para silenciar meus inimigos [R]

A recitação se alongou enquanto a lista de armamentos espirituais se estendeu para "martelos", "espadas", "fogo", "granadas", transfigurando a espera por Deus em um verdadeiro ataque orquestrado ao diabo e sua horda.

Algumas horas depois, mudamos de ânimo radicalmente mais uma vez, e a escuridão deu lugar à luz enquanto Ocran nos guiava por uma sessão final de louvação. Através de uma dinâmica retórica homóloga à pregação de Richard no dia anterior, terminamos a performance exatamente onde havíamos começado: esperando e habitando o tempo da salvação. Fomos transportados a ele por meio de palavras de agradecimento e visões da redenção, como "Minha esperança está em sua Palavra. Estamos esperando por suas promessas. Seus favores me abençoam. Toda glória para o Cordeiro de Deus", ou declarações mais intimas de amor e apreciação, tais como "Existe um homem. Seu nome é Jesus. Ele é tão importante para mim".

Findas as louvações, começamos a andar de volta para nosso dormitório. O antropólogo estava visivelmente exausto, se não entediado, em sua falta de recursos para esperar por Deus. Meus companheiros, por contraste, estavam supreendentemente energizados, apesar de sua impressionante exibição de atletismo religioso. Eles conversavam excitados e contavam piadas, como se não tivessem, há apenas alguns minutos, reclamado milagres e atacado demônios. Caímos no sono rapidamente. Às 7 da manhã, Richard me acordou para me contar que 
estava andando de novo para a mata com Sylvester e Abekan, para terem uma sessão conjunta de quiet time, uma técnica carismática de meditação (Reinhardt, 2017). Ainda exausto, acenei com a cabeça e voltei a dormir, enquanto um novo dia de espera por Deus começava em Atwea.

\section{Os Futuros Virtuais e as Forças da Espera e da Impaciência}

[...] mas aqueles que esperam no Senhor renovam as suas forças. Voam bem alto como águias; correm e não ficam exaustos, andam e não se cansam..(ISAÍAS, 40:31)

Minha intenção neste artigo foi explorar etnograficamente como pentecostais em Gana integram, ao invés de oporem ou dissolverem, a espera da fé e a experiência pós-colonial de emergência. Como destaca Mbembe (2001, p. 1-23), o "tempo em movimento" da pós-colônia africana insiste em transbordar capturas meta-narrativas, requerendo uma sensibilidade teórica mais rente aos vários modos cotidianos de se fazer a vida vivível, de se habitar e navegar seu vórtice temporal. Destaquei que, como parte integral dessa temporalidade inerentemente contingente, em que o secular e o religioso se entrelaçam de múltiplas formas, a espera cristã não é nem necessariamente suspendida nem ossificada, tendendo a se proliferar em tipos e intensidades.

O estilo de vida de Richard exemplifica como tentativas de se estabilizar o "sujeito africano da crise" através de noções de agência e pessoa univocais tendem inevitavelmente a torná-lo inautêntico, contraditório ou simplesmente ininteligível. Quando Richard jejua e ora em horas de privação, ele parece ser um renunciante extramundano. Mas quando ele usa seus recursos escassos como "dinheiro semente", ele aparece como um materialista desesperado. Quando ele prega sobre o iminente retorno de Cristo, ele é messiânico. Mas quando ele ventila promessas de milagres, está pronto para abraçar o aqui e agora. Quando ele certifica as suas audiências de que não está pregando por dinheiro, ele aparece santificado. Mas quando ele recebe essas doações de bom grado, pode parecer hipócrita. Essa dinâmica heteroglóssica encontra um ápice em sua própria missão de vida: atrair pessoas para 
uma comunidade cristã que, de acordo com as suas próprias palavras, é permeada por falsários, tricksters e endemoniados. Bem-vindo ao "fim dos tempos", uma historicidade que caracterizei não como um sistema cultural ou uma reposta narrativa conferindo "significado" a um contexto instável e errático, mas como parte de um equipamento ético e espiritual cuja finalidade é, sobretudo, agir sobre si mesmo e sobre eventos simultaneamente, incluindo não um, mas vários cronótopos da espera.

Esperar por Deus em Atwea é uma prática tão plurivocal quanto a vida e a pregação de Richard. O tempo da salvação não é apenas replicado nessa prática em certos estágios lineares de sua série ritual, como durante as louvações ou as confissões e arrependimentos. Ele se apresenta por toda a performance através do poder imanente do Espírito Santo, a força energética que, em última instância, dirige a espera por Deus adiante. Esperar por Deus é literalmente uma oração do fim dos tempos, transportando os participantes através de visagens e vislumbres da vida eterna, dos milagres e dos mundos ocultos. Essa prática pode ser abordada como um "ritual", uma evento extraordinário dotado de efeitos catárticos, mas eu preferi abordá-la como parte inerente de uma forma de vida, um conjuntos de tecnologias do sujeito que operam através da "transformação do logos em ethos" (Foucault, 2005, p. 238), de axiomas teológicos em aptidões corporais. Como uma prática "ethopoiética" (Foucault, 2005), esperar por Deus renova e empodera o sujeitos renascidos em Cristo ao equipá-los com instrumentos de navegação temporal que, em última instância, são modos de existência: a existência-enquanto-espera. Eu concluo considerando duas disposições temporais de longo prazo embutidas em dois dispositivos particulares do equipamento de vida pentecostal: as "confissões positivas" e a "batalha espiritual".

Uma definição estrita da doutrina pentecostal das "confissões positivas" seria "uma proposição que reclama as provisões e promessas de Deus no presente" (Coleman, 2000, p. 28). Elas são enunciadas durante a pregação, sessões de cura, orações e na vida cotidiana. Uma das minhas interlocutoras em Acra, por exemplo, enunciava "confissões positivas" diariamente para seu filho, que ainda estava 
em seu útero. O recurso generalizado a essa técnica retórica reflete o engajamento geral dos pentecostais com uma ideologia linguística que sublinha a capacidade das palavras-de-fé gestarem realidades, animadas pela força pneumática do Espírito Santo (Coleman 2006). Como vimos, as confissões positivas conferiram uma dinâmica circular à oração de nosso grupo em Atwea, que foi composta de uma série de passagens retóricas de pleitos submissos para cenas de antecipação e agradecimentos: Pais, nos dê a unção - Eu vejo seu óleo caindo sobre nossas cabeças - Obrigado Senhor. Apesar desse dispositivo eventualmente decair em "autoajuda", acredito que as confissões positivas sejam mais do que meros truques retóricos preocupados em elevar os estados de ânimo dos praticantes. De fato, as confissões positivas revelam o modo dominante dos pentecostais exercitarem a força prospectiva da fé enquanto "prova das coisas que não vemos" (Hebreus 11:1), seu modo singular de esperar por Deus.

Quando abordada como parte de uma disposição temporal mais ampla, um habitus crente, as confissões positivas engendram uma modalidade ética de atenção. Simone Weil (1996, p. 197 e 195) destaca a centralidade da atenção para se entender a espera religiosa, definindo a própria religião como "atenção animada pelo desejo", "um desejo que salva". A faculdade da atenção não é nem ação nem passividade, sendo central para a orientação temporal de um sujeito que habita o interior de uma economia da graça, em que a agência última pertence somente a Deus. Mas o estilo de espera pentecostal é também distinto da fenomenologia quietista de Weil (1996, p. 111), para quem a atenção religiosa implica fundamentalmente em "suspender nosso pensamento, deixando-o desconectado, vazio e pronto para ser penetrado pelo Objeto". As confissões positivas revelam e avançam uma atenção resiliente e mesmo atlética, que resiste a ser tragada pelas múltiplas distrações, contingências e violências da vida quotidiana ao moverse na direção de seu Objeto desejosamente, por meio de constante autoestimulação ritual, imaginária e volitiva. Elas não são um simples encantamento, um "Que seja feito a minha vontade", mas sim uma forma de esperar por Deus ao reclamar promessas, que exercita os bens inteiros da espera cristã ao abraçar a sua eficácia miraculosa no agora. 
Acredito que muito da gravitas e do senso de dignidade transpirado por alguém como Richard reflete como o milagre adentra a sua dura vida quotidiana enquanto um Objeto virtual, ou seja, algo real, mas não plenamente atual, "a insistência daquilo que não está dado" (Zourabichvili, 2012, p. 215; Reinhardt, 2015). Isso significa que Richard não apenas "pensa grande". Ele habita o futuro virtual a ele reservado por Deus. Nesse sentido, Richard literalmente não é o que eu vejo, incluindo a sua precariedade. Ele é aquilo que ele está em vias de se transformar, de acordo com o tempo de Deus.

$\mathrm{O}$ mesmo raciocínio pode ser aplicado à teologia da batalha espiritual, que pode ser definida de uma forma estrita como uma série de ações rituais visando destruir demônios, indo de exorcismos chamativos nos púlpitos de igrejas ao hábito cotidiano de "cancelar" problemas evocando o "nome de Jesus". Sylvester me contou sobre um curioso hábito que desenvolveu durante seu aprendizado religioso com Akosua: ele "cancela pensamentos maus", memórias tristes, pensamentos de autocomiseração, intuições que ele julga pecaminosas, ao imediatamente evocar o nome de Jesus internamente, ou seja, ao batalhar espiritualmente no púlpito de sua vida íntima. De fato, para os pentecostais, demônios, assim como o miraculoso, exercem uma presença conspícua e ordinária em suas vidas. Em consonância, o arsenal ético e espiritual que eles mobilizam para submeter o mal pode ser retrospectivo, post factum, endereçando-se a ataques já realizados, mas também prospectivos ou preventivos, logo dando vazão a uma disposição temporal durável. Apesar de nosso grupo de oração ter endereçado casos específicos de oposição demoníaca em Atwea, a maior parte da batalha espiritual que eles travaram naquela noite não tinha Objeto retrospectivo em mente. Em suma, eles oraram mormente contra "ataques aos seus destinos". Seguindo o raciocínio acima, podese dizer que ele batalharam contra forças do mal contraefetuando o futuro virtual que Deus reservou para eles. Significa que ao invés de opor a espera por Deus à batalha espiritual, eu prefiro entender essa prática agonística de fé como uma forma de espera via ataque preventivo.

A maioria dos pentecostais em Gana toma como um dado axiomático que o mundo assim como está - o mesmo mundo em que 
a salvação foi amplamente concedida e que milagres estão sempre a um passo de se atualizarem - pertence ao demônio, o cristão sendo nele um perene estrangeiro. Ser cristão, esperar por Deus na pós-colônia, é continuamente afinar seus corpos para estar em contato com a vontade e o poder de Deus, logo também batalhar contra a pulsão natural do diabo de predar seu futuro. É no interior desta ecologia religiosa tensa que várias espécies de fé carismática afloram em Gana: algumas mais orientadas para a salvação, outras mais orientadas para os milagres ou os demônios.

Fixação univocal em qualquer um desses cronótopos produz seus próprios inputs negativos na ética da espera Cristã: antecipações ansiosas do fim; uma busca estéril e mágica por milagres, que geralmente leva à descrença e abandono da fé; e uma obsessão paranoica com o "oculto", que impede que a confiança brote no dia-a-dia. Conversos maduros com Richard produzem suas próprias químicas temporais, suas éticas e poéticas da temporalidade pentecostal, de modo a tornarem seu presente habitável. Como demonstrei, esperar por Deus em Atwea é uma jornada pedagógica por todos esses cronótopos, logo também um exercício de phronesis (MacIntyre, 1984), de cultivo do equilíbrio éticotemporal. Ser um cristão maduro é assim esforçar-se por navegar de forma coerente e sempre alerta o pluralismo temporal da pós-colônia, ao invés de simplesmente estar jogado em seu fluxo contingente de forma passível.

É indicativo que toda vez que debates sobre imoralidade, falsidade e outras chagas afetado o corpo de Cristo em Gana emergiram dentro de nosso grupo em Atwea, a causa principal levantada para justificá-las não foram demônios, ou como países africanos seriam especialmente expostos à sua agência por causa da "idolatria" de seus ancestrais (Meyer, 1998). Afinal de contas, para os pentecostais, demônios apenas fazem o que eles devem fazer, mesmo quando operam em diferentes intensidades territoriais. A principal força evocada permitindo que a crise contaminasse a igreja foi a proliferação de "Cristãos impacientes". Durante uma de nossas conversas informais, Ocran deu tons mais viscerais a esse tipo de cristão: “É isso que a vida fez com os cristãos de Gana. Tanto sofrimento [...] Eles oram por comida, você vê? [Virando- 
se para mim, enquanto eu pensava em Richard] Um cristão não deve orar por comida. Não é assim que se aborda uma pessoa importante como Deus. Um cristão deve orar pela graça de Deus, para fazer coisas grades. [Richard: Amém.] As pessoas desaprenderam a esperar por Deus neste país".

"Cristãos impacientes" são aqueles que exauriram a sua aptidão de esperar por meio de uma superexcitação das esperanças de curto prazo, uma mera projeção não transformadora da temporalidade da sobrevivência na temporalidade cristã. Suas atenções foram, em suma, devoradas pela vontade voraz "do mundo", a ponto de não serem mais aptos a adentrar as artes cristãs da espera. Isso não é apenas uma questão de limites materiais empíricos, embasada por uma oposição simplista entre o mudo da necessidade e o mundo da liberdade. Como eu argumentei, a vida de alguém como Richard é constantemente assombrada pelo fantasma da necessidade e se desenrola como uma série quase infinita de estratégias de improviso. Mesmo assim, essa mesma vida transmite um sentimento sensível de propósito, a "força da espera". Diferente de "cristãos impacientes" e outros sujeitos tragados pelo Zeitgeist pós-colonial, Richard não está atolado em um "presente estagnado", "acometido pela imobilidade e dor", "um presente que se estende de forma sem fim" (Scott, 2014a, p. 6). Ele vive em um futuro emergente. A diferença que eu postulei entre precariedade eticamente infértil e vulnerabilidade eticamente fértil não se faz accessível apenas pelo que se vê, que em ambos os casos é precariedade e contingência. Mas ela aparece de forma palpável e muitas vezes deslumbrante para o antropólogo secular quando este afina a sua própria atenção etnográfica para entender como, e se, essas formas de vida alternativas se movem, enquanto esperam.

\section{Notas}

1 Gostaria de agradecer Rogério Brittes Pires por seus comentários críticos a versões anteriores deste artigo.

2 Ver Lester (2003), Mahmood (2005, p. 153-188) e Hirschkind (2006, p. 173-174) por abordagens igualmente atentas à natureza pedagógica e encorporada (embodied) da espera cristã e islâmica.

3 Como destaca Susan Harding (1994), as histórias secular e bíblica não são simplesmente contrastadas ou colocadas em paralelo pelos evangélicos, uma sendo ilusória, 
a outra literalmente verdadeira. Essas temporalidades são fundidas figurativamente ou tipologicamente (Auerbach, 1997; Reinhardt, 2016) na prática.

4 O estatuto miraculoso de Atwea é hoje parte da imaginação popular ganense, como exemplificado pelos filmes populares Atwea l e 2, uma série de batalhas travadas por um pastor-herói contra feiticeiros e criaturas ocultas bizarras, de acordo com a estética teotecnológica analisada em detalhes por Meyer (2015).

\section{Referências}

AGAMBEN, Giorgio. Homo Sacer: o Poder Soberano e a Vida Nua I. Belo Horizonte: Editora UFMG, 2002.

ASAD, Talal. Formations of the Secular: Christianity, Islam, Modernity. Stanford: Stanford University Press, 2003.

ASAMOAH-GYADU, Kwabena. African Charismatics: Current developments within independent indigenous Pentecostalism in Ghana. Leiden: Brill, 2005.

AUERBACH, Erich. Figura. São Paulo: Ática, 1997.

BAKHTIN, Mikhail. The dialogic imagination: four essays. Austin: University of Texas Press, 1981.

BAYART, Jean-Francois. 'Les Églises chrétiennes et la politique du ventre: le partage du gâteau ecclésial', Politique Africaine, [S.l.], v. 35, p. 3-26, 1989.

CANNELL, Fenella. Introduction: the anthropology of Christianity In: CANNELL, Fenella, (Ed.). The Anthropology of Christianity. Duke University Press, 2006. p. 1-50.

COLEMAN, Simon. The globalisation of charismatic Christianity spreading the gospel of prosperity. Cambridge: Cambridge University Press, 2000.

. Do You Believe in Pilgrimage? Communitas, Contestation and

Beyond. Anthropological Theory, [S.l.], v. 2, n. 3, p. 355-368, 2002.

. Materializing the Self: Words and Gifts in the Construction of Charismatic Protestant Identity. In: CANNELL, F. The Anthropology of Christianity (Ed.). Durham: Duke University Press, 2006. p. 163-184.

COMAROFF, Jean; COMAROFF, John. Of revelation and revolution. Chicago: University of Chicago Press, 1991.

. Millennial Capitalism: First Thoughts on a Second Coming. Public Culture, [S.l.], v. 12, n. 2, , 2000. p. 291-343.

. Theory from the South or, How Euro-America Is Evolving toward Africa. Boulder: Paradigm Publishers, 2012. 
CSORDAS, Thomas. Somatic Modes of Attention. Cultural Anthropology, [S.l.], v. 8, n. 2, p. 135-56, 1993.

DeBOECK, Filip.Inhabiting ocular ground: Kinshasa's Future in the Light of Congo's Spectral Urban Politics. Cultural Anthropology, [S.l.], v. 26, n. 2, p. 263-286, 2011.

DERRIDA, Jacques. Espectros de Marx. Rio de Janeiro: Relume Dumara, 1994.

FABIAN, Johannes. Moments of Freedom: Anthropology and Popular Culture. Charlottesville: University Press of Virginia, 1998.

FAUBION, James. Toward an anthropology of ethics: Foucault and the pedagogies of auto-poiesis. Representations, [S.l.], v. 74, n. 1, p. 83-104, 2001.

FERGUSON, James. Global shadows: Africa in the neoliberal world order. Durham: Duke University Press, 2006.

FOUCAULT, Michel. Technologies of the Self. In: RABINOW, Paul (Ed.). Ethics: subjectivity and truth: essential works of Foucault 1954-1984. New York: New Press, 1997. p. 223-253.

. The hermeneutics of the subject. New York: PalgraveMacmillan, 2005.

A coragem da verdade. São Paulo: Martins Fontes,2011.

FREEMAN, Dana. Pentecostalism and development churches, NGOs and social change in Africa. New York: Palgrave Macmillan, 2012.

FREI, Hans. The "Literal Reading" of Biblical Narrative in the Christian Tradition: Does it Stretch or Will it Break? In: MCCONNELL, F. (Ed).The Bible and the Narrative Tradition. Oxford: Oxford University Press, 1986. p. 36-77.

GARRIOT, William; O'NEILL, Kevin. Who is a Christian? Toward a dialogic approach in the anthropology of Christianity. Anthropological Theory, [S.l.], v. 8, n. 4, p. 381-398, 2008.

GIFFORD, Paul. Ghana's new Christianity: Pentecostalism in a globalizing African economy. Bloomington: Indiana University Press, 2004.

GIRARD, René. Deceit, desire and the novel: self and other in literary structure. Baltimore: Johns Hopkins University Press, 1976.

GOLDSTONE, Brian. Life after sovereignty. History of the Present, [S.l.], v. 4, n. 1, p. 97-113, 2014.

GUYER, Jane. Prophecy and the Near Future: Thoughts on Macroeconomic, Evangelical and Punctuated Time. American Ethnologist, [S.l.], v. 34, n. 3, p. 409-421, 2007. 
HAGE, Ghassan. Introduction. In: HAGE, Ghassan. (Ed).Waiting. Carlton: Melbourne University Press, 2009. p. 1-12.

HARDING, Susan. Imagining the Last Days: The Politics of Apocalyptic Language. Bulletin of the American Academy of Arts and Sciences, [S.l.], p. 1-12, v. 48, n. 3, p. 14-44, 1994.

HASTINGS, Adrian. A history of African Christianity, 1950-1975. Cambridge: Cambridge University Press, 1982.

HAYNES, Naomi. Moving by the Spirit: Pentecostal Social Life on the Zambian Copperbelt. Berkeley: University of California Press, 2017.

HILGERS, Mathieu. The historicity of the neoliberal state. Social Anthropology, [S.l.], v. 20, n. 1, p. 80-94, 2012.

HILL, Jane. The Voices of Don Gabriel: Responsibility and Self in a Modern Mexicano Narrative. In: MANNHEIM, Bruceand; TEDLOCK, Dennis (Ed.). The Dialogic Emergence of Culture. Urbana: University of Illinois Press, 1995. p. 97-147.

HIRSCHKIND, Charles. The ethical soundscape cassette sermons and Islamic counterpublics. New York: Columbia University Press, 2006.

. Existe um corpo secular? Religião e Sociedade, [S.l.], v. 37, n. 1, p. 175-89, 2017.

HONWANA, Alcinda. The Time of Youth: Work, Social Change and Politics in Africa. Sterling: Kumarian Press, 2012.

INGOLD, Timothy. The perception of the environment: essays on livelihood, dwelling and skill. London: Routledge, 2000.

KEANE, Webb. Ethical Life: its Natural and Social Histories. Princeton: Princeton University Press, 2015.

KIRSCH, Thomas. From the Spirit's Point of View. Ethnography, Total Truth and Speakership. In: ZENKER, Olaf; KUMOLL, Karsten (Ed.).

Beyond Writing Culture: Current Intersections of Epistemologies and Practices of Representation. Oxford: Berghahn, 2010. p. 89-112.

KOSELLECK, Reinhart. Futuro Passado: contribuição à semântica dos tempos históricos. Rio de Janeiro: Contraponto, 2006.

LARKIN, Brian; MEYER; Birgit. Pentecostalism, Islam, and culture: new religious movements in West Africa. In: AKYEAMPONG, Emmanuel (Ed.). Themes in West Africa's history. Oxford: James Currey. 2006. p. 286312 .

LESTER, Rebecca. The Immediacy of Eternity: Time and Transformation in a Roman Catholic Convent. Religion, [S.l.], v. 33, n. 3, p. 201-219, 2003. 
MAHMOOD, Saba. Politics of piety: the Islamic revival and the feminist subject. Princeton: Princeton University Press, 2005.

. Religious reason and secular affect: an incommensurable divide?

Critical Inquiry, [S.l.], v. 35, n. 4, p. 836-862, 2009.

MAINS, Daniel. Neoliberal Times: Progress, Boredom, and Shame among Young Men in Urban Ethiopia. American Ethnologist, [S.l.], v. 34, n. 4, p. 659-673, 2007.

MAUSS, Marcel. A prece. In: OLIVEIRA, R. C. de (Org.). Marcel Mauss. Rio de Janeiro: Ática, 1979. p. 103-146.

MBEMBE, Achilles; ROITMAN, Janet. Figures of the Subject in Times of Crisis. Public Culture, [S.l.], v. 7, n. 2, p. 323-352, 1995.

MBEMBE, Achilles. Afriques indociles: christianisme, pouvoir et Etat en société postcoloniale. Paris: Karthala, 1988.

2001.

On the postcolony. Berkeley: University of California Press,

MEYER, Birgit. Make a Complete Break With the Past: Memory and PostColonial Modernity in Ghanaian Pentecostalist Discourse. Journal of Religion in Africa, [S.l.], v. 28, n. 3, p. 316-49, 1998.

. Pentecostalism and Neo-liberal Capitalism: Faith, Prosperity and Vision in African Pentecostal-Charismatic Churches. Journal for the Study of Religion, [S.l.], v. 20, n. 2, p. 5-28, 2007.

Sensational movies: video, vision, and Christianity in Ghana. Berkeley: University of California Press, 2015.

MARSHALL, Ruth. Political spiritualities the Pentecostal Revolution in Nigeria. Chicago: University of Chicago Press, 2009.

ODURO-FRIMPONG, Joseph. Sakawa Rituals and cyberfraud in Ghanaian popular video movies. African Studies Review, [S.l.], v. 57, n. 2, p. 131 147, 2014.

PIOT, Charles. Nostalgia for the future West Africa after the Cold

War. Chicago: University of Chicago Press, 2010.

REINHARDT, Bruno. Tapping into the anointing: Pentecostal pedagogy, connectivity, and power in contemporary Ghana. Berkeley: Ph.D. Thesis in Anthropology, University of California, 2013.

. Poder, história e coletaneidade: os lugares do colonialismo na antropologia sobre a África. Revista de Antropologia, [S.l.], v. 57, p. 329375, 2014. 
. A Christian plane of immanence? Contrapuntal reflections on Deleuze and Pentecostal spirituality. HAU: Journal of Ethnographic Theory, [S.l.], v. 5, n. 1, p. 405-436, 2015.

. De epifania a método: a teopolítica do testemunho em um seminário pentecostal em Gana. Religião e Sociedade, [S.l.], v. 36, n. 2, p. 44-70, 2016.

. Praying until Jesus returns: commitment and prayerfulness among charismatic Christians in Ghana. Religion, [S.l.], v. 47, n. 1, p. 5172, 2017.

ROITMAN, Janet. Anti-Crisis. Durham: Duke University Press, 2013. SCOTT, David. Refashioning futures: criticism after postcoloniality. Princeton: Princeton University Press, 1999.

. Conscripts of modernity: the tragedy of colonial enlightenment. Durham: Duke University Press, 2004.

. Omens of Adversity: Tragedy, Time, Memory, Justice. Durham: Duke University Press, 2014a.

. The tragic vision in postcolonial time. PMLA, [S.l.], v. 129, n. 4, p. 799-808, 2014b.

SCHUTZ, Alfred. Making music together: a study in social relationship. Social Research, [S.l.], v. 18, n. 1, p. 76-97, 1955.

SHIPLEY, Jesse. Comedians, Pastors, and the Miraculous Agency of Charisma in Ghana. Cultural Anthropology, [S.l.], v. 24, n. 3, p. 523-552, 2009.

. Africa in theory: a conversation between Jean Comaroff and Achille Mbembe. Anthropological Quarterly, [S.l.], v. 83, n. 3, p. 653$678,2010$.

SIMONE, Abdoumaliq. For The City Yet To Come: Changing African Life In Four Cities. Durham: Duke University Press, 2004.

TARDE, Gabriel. On Communication and Social Influence: Selected Papers of Gabriel Tarde. Chicago: University of Chicago Press, 1969.

WEIL, Simone. Waiting for God. New York: Putnan \& Sons, 1996.

ZOURABICHVILI, François. Deleuze: A Philosophy of the event: together with The Vocabulary of Deleuze. Edinburgh: University of Edinburgh Press, 2012.

Recebido em 04/08/2017

Aceito em 12/10/2017 